The following paper by Professor D. A. Gilchrist, entitled "Basic Slag and its Place in the Development of Agriculture," was received subsequent to the meeting:

\title{
BASIC SLAG AND ITS PLACE IN THE DEVELOPMENT
}

\section{OF AGRICULTURE.}

\author{
By Professor D. A. Gilchrist, Armstrong College, \\ Newcastle-on-Tyne.
}

The following are extracts from a paper on "Basic Slag as Affecting Agricultural Development," read to the Society of Chemical Industry on February 5th, 1917, by Professor Louis and myself :-

"Phosphatic manures have enormously developed the production of farm and garden crops. Soils can obtain nitrogen by the growth of leguminous plants, and to a certain extent, by other means without the direct addition of nitrogen to the soil; but the phosphates removed by crops must be returned by direct manuring, and farmyard manure does not return these phosphates in a sufficient manner, because so much of these are retained by the animal. Bones and bone ash were used to some extent to replace phosphates early in the nineteenth century. When Liebig and Lawes, about 1840, found that bones and mineral phosphates could be rendered more effective by treatment with sulphuric acid, so as to make part of the phosphates soluble, an enormous impetus was given to the growth of swedes and turnips, the crops of which were greatly increased by the judicious application of soluble phosphates (superphosphate) upon soils where phosphate exhaustion had been long in progress. Wornout pastures, also suffering from phosphate exhaustion, gave a remarkable response to these phosphatic manures. When superphosphate had been used for a considerable time, it came to be realised that this manure did not give as good results on peaty soils or on soils poor in lime as on soils in which a fair amount of lime was present. The conclusion was therefore reached that the soluble phosphates in superphosphate gave the best results when they were precipitated into insoluble phosphate in the soil, and were thus well distributed in the soil in a fine state of division."

"Until about 1880 the supply of phosphatic manures was met to some extent by bone meal, but chiefly by mineral phosphates, the bulk of the latter being converted into superphosphate, while a small quantity was used as ground phosphates. The discovery by Messrs. Gilchrist and Thomas that it was possible to remove phosphorus from iron and to transfer it to the slag in making steel, gave rise to the so-called Gilchrist.Thomas or basic Bessemer process of steel making, and it was soon found that the slag produced in this operation possessed valuable manurial properties." 
"The late Dr. Andrew Aitken, Chemist of the Highland and Agricultural Society of Scotland, conducted trials for that Society at the Pumpherston Agricultural Station, near Edinburgh, some years before 1889 , which proved that rock phosphates or mineral phosphates, when finely ground, gave quite good results. About this time, however, basic slag came into general use, and phosphate of lime could be purchased in this manure at about $9 \mathrm{~d}$. a unit, whereas the same in finely-ground rock phosphate cost over 1s. $2 \mathrm{~d}$. a unit. As Dr. Aitken found that basic slag phosphates gave better results than mineral phosphates, the use of the latter, which had begun among farmers in Scotland, was stopped, and basic slag came into general use, as it was somewhat more effective, and cost less per unit of phosphate of lime."

"At Cockle Park, on heavy loam soil of a poor character, a dressing of $10 \mathrm{cwt}$. an acre of high grade basic slag, applied once in six years, has increased the seeds hay crops by over 10 ewt. an acri in each of the three following years after its application; oats have been increased by over 10 bushels an acre in the fourth year thereafter, swedes by over 4 tons an acre in the fifth year thereafter, and barley by 4 bushels an acre in the sixth year thereafter. At pre-war prices, valuing hay at $£ 3$ a ton, oats at 3 s. a bushel, swedes at $7 \mathrm{~s}$. $6 d$. a ton, and barley at $4 \mathrm{~s}$. a bushel, this gives a total of $£ 82 \mathrm{~s}$. $6 \mathrm{~d}$. as the increased value of the crops for six years after the application of $10 \mathrm{cwt}$. high grade basic slag, which, at pre-war prices, would cost about 25s. On the sandy loam soils at the same centre, a dressing of $5 \mathrm{cwt}$. an acre of high grade basic slag has probably increased the following seeds hay crop by $10 \mathrm{cwt}$. an acre, the oats in the second year by 10 bushels an acre, the swedes in the third year 3 tons an acre, and the barley in the fourth year by 4 bushels an acre. This gives an estimated return of $£ 418 \mathrm{~s}$. 6d. from the application of 5 cwt. basic slag, at a cost of about 12s. 6d."

" In the Hanging Leaves fields at Cockle Park, where a pasture of the poorest character has been treated with basic slag alone, the increased gains made by the cattle and sheep during the past eleven years show a gain of about $7 \mathrm{~s}$. 6d. for each shilling spent on basic slag."

"The foregoing estimates of increased crops from the application of basic slag are based on crop results at Cockle Park. It should be noted that the basic slag owes much of its effects to the inclusion of wild white clover in seeds mixtures. This plant is enormously developed by basic slag, and the nitrogen collected by its roots is of the greatest help to the phosphatic residues of the slag in increasing the various crops."

"The amount of basic slag now used annually for manurial purposes in this country may be between 200,000 and 300,000 tons. It has already been estimated that the total amount of basic slag produced in this country is now about 850,000 tons, but, as much of this is of low grade, the total amount produced may be equal to about 600,000 tons of high grade basic slag."

"The total area under crops and grass in the United Kingdom (not including mountain and heath land) is under 47 million acres. Assuming that 250,000 tons of basic slag are now used for agricultural purposes in the United Kingdom, this would provide a 
dressing of $5 \mathrm{cwt}$. of basic slag per acre every fourth year for four million acres. If the total basic slag produced in this country were used for agricultural purposes (estimated to be equal to 600,000 tons high grade basic slag), the total area of land so treated would be increased to $9,600,000$ acres, and it can be realised from the foregoing Cockle Park figures how enormously the food production of this country would be increased."

"In this country there were produced annually before the war from 820,000 to 850,000 tons of superphosphate, of which about 76,000 tons were exported. These figures give some idea of the relative amounts of superphosphate and basic slag used before the war for manurial purposes. Superphosphate is produced mainly from rock phosphates, of which nearly 600,000 tons were imported to this country in 1913."

The following notes are extracted from two books by Dr. C. Hopkins, Professor of Agronomy, University of Illinois :-

In "The Farm that won't wear out" he emphasises that phosphorus is the master key to permanent agriculture. He points out that the annual export of phosphates from U.S.A. to Europe is of the value of $5,000,000$ dollars $(£ 1,000,000)$. He summarises trials of different phosphates at the Pennsylvanian State College (12 years), Maryland Experiment Station (12 years), the Rhode Island Experiment Station, the Massachusetts Experiment Station, and the Ohio Agricultural Experiment Station (16 years).

At Pennsylvania the yearly average gain per acre for 12 years was 2.12 dollars from raw phosphate and 48 cents from acid phosphate. At Maryland the raw phosphate produced a higher total average yield than acid phosphate at less than half the eost. At Rhode Island, hay and grain gave increases per acre of 14,580 pounds from raw phosphates and 14,550 pounds from acid phosphate on unlimed land; lime and raw phosphate produced 27,030 pounds, and lime and acid phosphate, 29,690 pounds increase; the acid phosphate cost three times as much as the raw phosphate. At Massachusetts raw phosphate ranked above acid phosphate, both as an average for the entire period, and as an average between 1895 and 1900 . Where no phosphate was applied only 55 per cent. as much was produced as where raw phosphate was used. At Ohio, on the average, $320 \mathrm{lb}$. raw phosphate per acre, applied with dung on clover sod, gave the following increases:-Maize, 8.4 bushels; wheat, 4.7 bushels; hay, .49 of a ton; all above dung alone. Under the same conditions $320 \mathrm{lb}$. acid phosphate, costing twice as much money, but with only half the phosphates, gave increases of $7 \frac{1}{2}$ bushels maize, 6.I bushels wheat, and .46 of a ton of hay.

On page 52 he states that the natural rock phosphate should be ground so that at least 90 per cent. passes through a sieve with 10,000 meshes to the square inch, and, of course, its content of phosphates should be guaranteed (60 to 75 per cent.). This ground phosphate he calls Raw Phosphate.

$\mathrm{He}$ goes on to state:-

" On my own farm I use about one ton per acre of raw phosphate once every six years, thus adding at least 250 pounds of phosphorus at a cost of less than 8 dollars; whereas 200 pounds of the commor 'complete' fertiliser per acre yearly would cost I2 dollars every 
six years, and would supply only 40 pounds of phosphorus. I do not use ' complete' fertilisers, because there is plenty of nitrogen in the air and plenty of potassium in the soil; and because, by growing and ploughing under plenty of clover, I not only secure nitrogen from the air and liberate potassium from the soil, but also liberate the phosphorus from the raw rock phosphate applied to the soil. In beginning the use of raw phosphate where the supply of organic manures is limited, I apply one ton of phosphate and 600 pounds of kainit in intimate connection, turn them under, preferably with organic matter, then add ground limestone if needed, and thus prepare to grow clover."

The foregoing summary of this book shows that the author's main idea is that phosphates, properly applied to the soil with the rjudicious growth of leguminous crops, will supply all the nitrogen that is wanted, as well as the phosphorus.

Dr. Hopkins' larger work, "Soil Fertility and Permanent Agriculture," is published by Ginn and Company, New York and London. It contains excellent summary tables of all the phosphate experiments referred to in the little book. On page 595 he deals with production of phosphate rock, and states that Florida, South Carolina, and Tennessee have for several years been the main sources of phosphate in U.S.A. The production of phosphate from South Carolina from the beginning of the industry in 1867 till the year 1888 , during which period that State was the only producer, was about $4 \frac{1}{2}$ million long tons for this whole period. In 1908 the marketed production of phosphate rock in U.S.A. was $2,400,000$ long tons, and the total value about $11,400,000$ dollars. About half of this was exported.

The world's production of phosphate rock in 1907 in metric tors was about:-

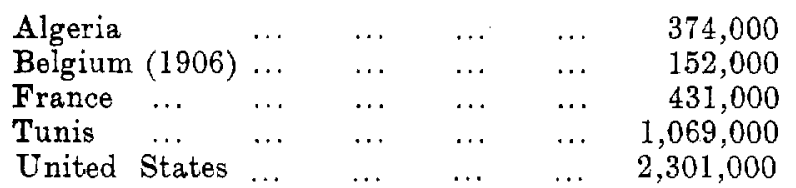

The foregoing information is quoted by the author from "Advance Chapter from Mineral Resources of the United States, Calendar year, 1908,' by Van Horn, of the U.S.A. Geological Survey. The author further states: "It would appear certain that the phosphate deposits of the U.S. are to be drained for the benefit of the worn-out farm lands of foreign countries." The exports of deposits from Florida, Tennessee, and South Carolina cannot be easily prevented, but the author suggests that this should be done with other phosphates and even with these to the fullest extent possible.

Dr. Hopkins' works are of the greatest importance in showing the important part that mineral phosphates take in the agriculture of the United States. They point out strongly our need of conserving and developing our resources of phosphates in the British Empire, and especially for our making the fullest use of our home resources of basic slag.

At Cockle Park, in the six years ending 1917, on the poor clay pasture of Tree Field, the untreated plot gave average annual live weight gains from sheep grazing on it of only $21 \frac{1}{3}$ lbs. an acre, whereas the repeated application of high grade basic slag (39 per

VOL. XVI-T17 
cont. phosphates) increased the average annual live weight gains to 103 lbs. an acre, or nearly fivefold. In the Hanging Leaves pasture fields, for the same six years, the average live weight gains per acre were 195 lbs. from cattle and sheep from pasture land (originally as poor as that of Tree Field), which receives a dressing of $5 \mathrm{cwt}$. an acre of high grade basic slag every third year. Three years? leys at Cockle Park, receiving one dressing of $10 \mathrm{cwt}$. an acre of high grade basic slag, gave average crops of about 42 cwt. hay an acre in each of the three years after the application of the slag. No other manure was used throughout the three years. The clover aftermaths were of a most valuable character for grazing, and as good in the second and third years as in the first. The oat crops that follow when these three years' leys are ploughed out are heavy and valuable, largely because of the good effects of the basic slag applied for the hay crops. The turnip crops which follow the oats evidently receive as much or even more benefit from the slag applied for the previous hay crops than from superphosphate applied direct to the swedes.

At Cockle Park basic slag, at about half the cost, proves a more effective manure for mangels and for beans than superphosphate.

The Guide, issued from Cockle Park annually, and other bulleting issued from that Station, give the full results of these and other trials. At that Station there is little need for the use of nitrogenous manures, because the judicious application of basic slag on the arable and pasture land stimulates clover herbage, which latter collects an abundant supply of nitrogen indirectly from the air. 